\title{
Analysis of Training Mechanism of Cultural-Industry Talents at Independent Colleges in Beijing, Tianjin and Hebei
}

\author{
Cheng CHENG \& Hong ZHANG \& Jia LIU \& Junling WEI \\ Polytechnic College, Hebei University of Science and Technology, Shijiazhuang, Hebei, China
}

\begin{abstract}
This article discusses the definitions of cultural industry and cultural-industry talents, the extension of the integrated training mode of cultural-industry talents in independent colleges, and their impact upon economic development and government policy making in Beijing-Tianjin-Hebei Area. The focus is on the following four aspects. First, government-led overall integration planning should be implemented. Second, the integration of higher education resources should be applied to the regional development to minimize costs. Third, complementary model of talents cultivation should be achieved to optimize education. Finally, social requirements should be met to maximize the demand for industry talents.

KEYWORD: cultural-industry talents; regional economy; integration of Beijing, Tianjin and Hebei; independent colleges
\end{abstract}

\section{THE CONNOTATIONS OF CULTURAL INDUSTRY AND CULTURAL-INDUSTRY TALENTS}

Currently, with the launch of China's 12th Five Year Plan, and with the deep concern of all sectors of society about "the development of cultural-industry prosperity," the research has been more and more systematic, comprehensive and diversified about the definitions of culture industry and cultural-industry talents, as well as the study of the connections among the three industries. For example, the methods, patterns, system-oriented research of cultivating cultural-industry talents, have become increasingly popular. Colleges and universities being the main output of talents cultivation, management and communication, have become the main research objects for theoretical, academic and political circles.

According to the related documents by China Ministry of Culture, the definition of generalized cultural-industry talents is related to the cultural system of cultural industry practitioners. Judging from the cultural and non-cultural sectors, culturalindustry talents and talents of other industries, have the characteristics of high correlation and intersectionality. Divided from the relatively narrow angle, cultural-industry professionals refer to those who are working in libraries, literature research centers, public cultural services, sectors such as arts and heritage sectors engaged in such work or service. These cultural-industry professionals are divided into two categories: technological culturalindustry talents, management cultural-industry talents, who are interrelated and intersected. Technological cultural-industry talents mainly refer to those whose work is to process, produce, design and create. Whose who can transform theory into productivity with their expertise and professional technology, and through creative work, are the core talents for the upgrade and fast development of culture industry, as well as the base of cultural industry. For instance, they create culture products of economic values from abstract concepts; they employ culture-related resources and intellectual abilities to create productivity values.

Management cultural-industry talents are those who change abstract symbols into physical values and human capitals, through their own management, economics, psychology or related disciplines of theoretical knowledge. For example, they evaluate their social environments in order to formulate the strategy for organizational development of the cultural industry and the sale of cultural products; they select cultural-industry and technology talents, cultural products in the planning, design, production, packaging, marketing and other related planning, coordination and operations; they timely adjust their business strategy of talents management from the perspective of the whole business. 
2 INTEGRATED CULTURAL-INDUSTRY

TALENTS TRAINING MODEL AT INDEPENDENT COLLEGES IN BEIJINGTIANJIN-HEBEI AREAS

\subsection{Introduction to the distribution of independent college resources in Beijing-Tianjin-Hebei area}

Since the appearance of independent colleges, they have been seen more than 10 years of development. They were attached to their mother schools between 1999-2002, entered the period of independence between 2003-2011, and now is at the stage of further development, whose integrated development model is one of the most important forms. In the national distribution of independent colleges of the four municipalities (Beijing, Tianjin, Shanghai, Chongqing), independent colleges in Beijing and Tianjin amount to $53 \%$. Independent colleges in the Beijing-Tianjin-Hebei region make up $9.83 \%$ of the national independent colleges, with a strong source of attraction and integration of investment. Independent colleges in Hebei province also has the feature of regional concentration, with its main distribution in Shijiazhuang, Baoding and Langfang cities, closely related with colleges in Beijing and Tianjin, thus reducing cost of collaboration. In cultural aspects, it is easy to reach consensus, which lays a solid foundation for the formation of cultivating model of cultural-industry talents in independent colleges. Of the national top 100 colleges, 9 are from Beijing-Tianjin-Hebei area, indicating that this region has initially formed concentrated networks in Beijing, Tianjin, covering Shijiazhuang, Baoding and Qinhuangdao, enhancing the interactive nature of independent colleges.

\subsection{The impact of integrated cultural-industry talents training model at independent colleges in Beijing-Tianjin-Hebei area}

With the development of "Twelfth Five Year Plan" and the strategic planning of Bohai Bay Economic Circle, new goals and challenges are facing the cultivation of innovative talents and the development of higher education. Compared higher education in Pearl River Delta, Yangtze River Delta, Beijing-Tianjin-Hebei education is less developed. For example, college graduates' contributions to the regional economic development are limited; the mobility is lower; the impact upon promoting the regional economy is less obvious; and the relationship with research centers is not closer. From the standpoint of talents training, the training of cultural-industry talents in independent college can optimize the industrial structure of the area. Therefore it is necessary to combine and balance independent colleges in the region. Integrated training model is the core. In essence, the integration is the study of how to collaborate for further development. First, independent colleges should be coordinated towards integrated talent-training model, and eliminate the risk of unnecessary competition. Second, the innovative training model is the key to integration mechanisms and educational philosophy of running a new system to strengthen internal cooperation among members, clarifying their needs. Therefore, the integration is the reasonable coordination of colleges in the region, especially the integration of higher education systems, for instance, administration, funding, integration of disciplines and enrollment, employment, human resources, teacher evaluation, teaching reform (such as reform of the curriculum, teaching materials, etc), teacher recruitment, professional title evaluation of staff, teaching integration, integration of postgraduate enrollment and employment. In this way, community and employers in the region can have the same standards and evaluations for cultural-industry talents; any level of college teaching can be placed in the same platform where teaches can learn from each other. The goals of the integration are as follows. First, the integration of talent cultivation can accelerate popularization of higher education in BeijingTianjin-Hebei area. Relying on the influence of Beijing and Tianjin, Hebei province can increase the number of human capital, upgrade human capital skills, improve cultivation system of human capital, further meet the needs of economic development, especially cultural development in Beijing, Tianjin and Hebei regions. Second, the integration can help build a scientific platform for higher education in Beijing-Tianjin-Hebei region, achieve optimization and improvement in Beijing-Tianjin-Hebei area. Third, the integration can help achieve higher overall education quality in Beijing, Tianjin and Hebei areas and significantly meet the regional demand for cultural industry professionals.

\subsection{Strategies and measures for integrated cultural- industry talents training model at independent colleges in Beijing-Tianjin-Hebei area}

\subsubsection{Government-led integration planning}

As a leader in the development of higher education, governments at all levels need to make full use of the "visible hand", that is, fiscal policies, laws and regulations, coordinating, collaborating and planning higher education in the region. The target of the planning is for economic development. Nonadministration is the base for the planning, so indirect monitoring should be the top priority. Independent colleges should be granted the right to independent development, an integration mode of development, so that various effective policies and resources will be made use of to the maximum degree. For example, special coordination 
departments should coordinate the talents cultivation.

\subsubsection{Minimum cost of integrated cultural-industry talents training model at independent colleges in Beijing-Tianjin-Hebei area}

The relationship with mother universities is the base for the development of independent colleges, which has a fundamental difference with other nongovernmental colleges. Based on reputation and social influence of their mother universities, independent colleges can make full use of the resources, such as school faculty and hardware. The cooperation and effective sharing of resources can minimize development costs. There will make great difference in learning and research, science and technology, higher learning, independent management, industrial structure, and regional economic development.

\subsubsection{Complementary mode of cultivating talents to optimize education}

Evaluation mechanisms, principles and standards should be established and improved in independent colleges. Independent colleges in the BeijingTianjin-Hebei region should learn from those from other regions, such as the Yangtze River Delta, Pearl River Delta, clearly defining their training objectives, roles in the service of local economy. Technical and management talents can be cultivated for the economic development of Beijing-TianjinHebei area, classified by broad categories, professions, and functions. Independent colleges in Beijing-Tianjin-Hebei area should establish evaluation systems to meet the needs of integrated cultural-industry talents training model, set up scientific, standardized, operational evaluation criteria of talents training to fulfill the requirements to improve the operating efficiency and coordination.

\subsubsection{Keeping up with social requirements to maximize the demand for industry talents}

It is necessary for cultural-industry personnel training at independent college to adjust its specialties to the market and new trend of employment in Beijing-Tianjin-Hebei Economic Area, for example, some professional and popular majors that society needs badly should be offered. Some indexes can be added to the evaluation system, such as employment rate, career adaptability, the employer' satisfaction and feedback of students to teaching. Independent colleges and employers should be actively guided to its realization of longitudinal link, representing the actual contact of the social and economic development, to bridge the gap between scientific research personnel, teachers and students, meeting the requirements of society to maximize the demand for industry talents.

\section{REFERENCES}

[1] Moklatari Kouider, Reichard Carla A, Garder Anne. The impact of Internet and Television Use on the Reading Habits and Practices College of Students. Journal of Adolescent \& Adult Literacy, v52 n7 p609-619 April 2009.

[2] Gallilc Jude D. Do They Read for Pleasure? Recreational Reading Habits of College Students. Journal of Adolescent \& Adult Literacy, v42 n6 p480-88 Mar 1999.

[3] Rhonda Ackermann edit, The Successful Business Plan, Paloalto Calip, 2000: 24-25P.

[4] Jerold Pearson. Comprehensive Research on Alumni Relationships: Four Years of Market Research at Stanford University. New Directions for Institutional Research, 1999, 10:52-53.

[5] The Carnegie Foundation Classification of Institution of Advancement of Higher Education of Teaching, the Carnegie 2000 Edition.

[6] George Psacharopoulos. Returns to Education, An Updated International Comparison, Comparative Education, 1981, 17(3):321-341P 